Note

\title{
PRODUCTION OF SINGLE SUPERPHOSPHATE LABELED WITH ${ }^{34} \mathrm{~S}$
}

\author{
Alexssandra Luiza Rodrigues Molina Rossete ${ }^{1}$; Josiane Meire Toloti Carneiro ${ }^{1}$; José Albertino \\ Bendassolli2*; Claudineia Raquel Oliveira Tavares²; Carlos Roberto Sant'Ana Filho ${ }^{2}$ \\ ${ }_{2}^{1}$ USP/CENA - Programa de Pós-Graduação em Ciências. \\ ${ }^{2}$ USP/CENA - Lab. de Isótopos Estáveis - C.P. 96 - 13400-970 - Piracicaba, SP - Brasil. \\ *Corresponding author<jab@cena.usp.br>
}

\begin{abstract}
Single superphosphate is currently one of the mostly used fertilizers as an alternative source for phosphorus and sulphur. Sulphur presents four stable isotopes ${ }^{32} \mathrm{~S},{ }^{33} \mathrm{~S},{ }^{34} \mathrm{~S}$, and $\left.{ }^{36} \mathrm{~S}\right)$ with natural abundances of $95.00 ; 0.76 ; 4.22$; and $0.014 \%$ in atoms, respectively. Single superphosphate labeled with the ${ }^{34} \mathrm{~S}$ isotope was obtained from a chemical reaction in stoichiometric amounts between $\mathrm{Ca}\left(\mathrm{H}_{2} \mathrm{PO}_{4}\right)_{2}$ and $\mathrm{Ca}^{34} \mathrm{SO}_{4} \cdot 2 \mathrm{H}_{2} \mathrm{O}$. Calcium sulphate $\left(\mathrm{Ca}^{34} \mathrm{SO}_{4} \cdot 2 \mathrm{H}_{2} \mathrm{O}\right)$ was enriched with $5.85 \pm 0.01$ atoms $\%$ of ${ }^{34} \mathrm{~S}$. The $\mathrm{Ca}\left(\mathrm{H}_{2} \mathrm{PO}_{4}\right)_{2}$ reagent was obtained from a reaction between $\mathrm{CaCl}_{2} \cdot 2 \mathrm{H}_{2} \mathrm{O}$ and $\mathrm{H}_{3} \mathrm{PO}_{4}$. The reaction between the $\mathrm{Ca}\left(\mathrm{H}_{2} \mathrm{PO}_{4}\right)_{2}$ thus produced and the labeled $\mathrm{Ca}^{34} \mathrm{SO}_{4} \cdot 2 \mathrm{H}_{2} \mathrm{O}$ compound was then performed to obtain the ${ }^{34} \mathrm{~S}$-labeled single surperphosphate. The thermal decomposition of the labeled superphosphate for the production of gaseous ${ }^{34} \mathrm{SO}_{2}$ was carried out under a vacuum line at $900^{\circ} \mathrm{C}$ in the presence of $\mathrm{NaPO}_{3}$. The isotopic determination of $\mathrm{S}$ (atoms $\%$ of ${ }^{34} \mathrm{~S}$ ) was carried out on an ATLAS-MAT model CH-4 mass spectrometer. The production yield of $\mathrm{Ca}\left(\mathrm{H}_{2} \mathrm{PO}_{4}\right)_{2}$ and labeled single superphosphate were approximately 97 and $99 \%$ respectively, and the purity level of the labeled single superphosphate was estimated as $96 \%$. No isotopic fractionation was observed in the production process of ${ }^{34} \mathrm{~S}$-labeled single superphosphate.

Key words: isotopic determinations, sulphur, stable isotopes, mass spectrometry, labeled compounds
\end{abstract}

\section{PRODUÇÃO DE SUPERFOSFATO SIMPLES MARCADO COM ${ }^{34} \mathrm{~S}$}

RESUMO: O superfosfato simples é um dos fertilizantes mais utilizados atualmente como fonte de fósforo e uma alternativa para enxofre. O enxofre apresenta quatro isótopos estáveis, ${ }^{32} \mathrm{~S},{ }^{33} \mathrm{~S},{ }^{34} \mathrm{~S} \mathrm{e}{ }^{36} \mathrm{~S}$, com abundância natural de 95,$00 ; 0,76 ; 4,22$ e $0,014 \%$ em átomos, respectivamente. O superfosfato simples marcado com ${ }^{34} \mathrm{~S}$ foi obtido a partir da reação química em proporção estequiométrica entre o $\mathrm{Ca}\left(\mathrm{H}_{2} \mathrm{PO}_{4}\right)_{2}$ e o $\mathrm{Ca}^{34} \mathrm{SO}_{4} \cdot 2 \mathrm{H}_{2} \mathrm{O}$. O Ca ${ }^{34} \mathrm{SO}_{4} \cdot 2 \mathrm{H}_{2} \mathrm{O}$ foi enriquecido com $5,85 \pm 0,01 \%$ em átomos de ${ }^{34} \mathrm{~S}$. O $\mathrm{Ca}\left(\mathrm{H}_{2} \mathrm{PO}_{4}\right)_{2}$ foi obtido a partir da reação entre $\mathrm{CaCl}_{2} \cdot 2 \mathrm{H}_{2} \mathrm{O}$ com o $\mathrm{H}_{3} \mathrm{PO}_{4}$. A decomposição térmica do superfosfato marcado para produção do ${ }^{34} \mathrm{SO}_{2}$ gasoso foi realizada em linha de vácuo a $900^{\circ} \mathrm{C}$ na presença de $\mathrm{NaPO}_{3}$. A determinação isotópica do $\mathrm{S}\left(\%\right.$ em átomos de $\left.{ }^{34} \mathrm{~S}\right)$ foi realizada no espectrômetro de massas. $\mathrm{O}$ rendimento da produção do $\mathrm{Ca}\left(\mathrm{H}_{2} \mathrm{PO}_{4}\right)_{2}$ e do superfosfato simples marcado foi em média 97 e $99 \%$, respectivamente, e a pureza do superfosfato marcado foi estimada como $96 \%$. Não foi observado fracionamento isotópico no processo de produção do superfosfato simples marcado com ${ }^{34} \mathrm{~S}$.

Palavras-chave: determinação isotópica, enxofre, isótopos estáveis, espectrometria de massas, compostos marcados

\section{INTRODUCTION}

Phosphorus is essential for plant development, helping in cell division and stimulating root development. In the industry, the decomposition of rock phosphate with sulphuric acid yields many different kinds of phosphate compounds, including the Single Superphosphate (SSP), which is one of the most important fertilizers applied as a phosphorus source for plants. These compounds also contain sulphur (S) (Havlin et al., 2005), an element presenting deficiency in different soils and plants (Bissani \& Tedesco, 1988; Tisdale et al., 1986). Isotope dilution techniques and the use of compounds labeled with stable isotopes have been widely employed in order to obtain information about the cycle of many elements especially nitrogen and sulphur (Awonaike et al., 1993).

Sulphur presents four stable isotopes ${ }^{32} \mathrm{~S},{ }^{33} \mathrm{~S}$, ${ }^{34} \mathrm{~S}$, and ${ }^{36} \mathrm{~S}$ ) with natural abundances of $95.02 ; 0.75$; 4.21 ; and $0.02 \%$ in atoms, respectively (Krouse et al., 
1996). Most studies based on the application of labeled $\mathrm{S}$ have used the ${ }^{35} \mathrm{~S}$ radioisotope (Sharma \& Kamath, 1991), however, the application of compounds labeled with a stable isotope like ${ }^{34} \mathrm{~S}$ presents advantages especially due to the fact of not being radioactive. Today it is important to stress a world tendency to use stable isotopes as tracers to replace radioactive techniques, especially in studies involving field experiments (Zhao et al., 2001). The first studies based on the application of ${ }^{34} \mathrm{~S}$-labeled stable isotopes were developed by Hamilton et al. (1991), Awonaike et al. (1993), and Trivelin et al. (2002). Studies aiming at the separation of the ${ }^{34} \mathrm{~S}$ isotope developed by Bendassolli et al. (1997) were able to produce many different labeled compounds such as $\left({ }^{15} \mathrm{NH}_{4}\right)_{2}^{34} \mathrm{SO}_{4}, \mathrm{~K}_{2}^{34} \mathrm{SO}_{4}, \mathrm{H}_{2}{ }^{34} \mathrm{SO}_{4}$ and $\mathrm{Ca}^{34} \mathrm{SO}_{4} \cdot 2 \mathrm{H}_{2} \mathrm{O}$ (Maximo et al., 2005; Rossete et al., 2006).

The aim of the present work was to produce a single superphosphate labeled with the ${ }^{34} \mathrm{~S}$ isotope in the form of $3 \mathrm{Ca}\left(\mathrm{H}_{2} \mathrm{PO}_{4}\right)_{2}+7 \mathrm{Ca}^{34} \mathrm{SO}_{4} \cdot 2 \mathrm{H}_{2} \mathrm{O}$ and the subsequent $\mathrm{S}$ isotopic determination (atoms $\%$ of ${ }^{34} \mathrm{~S}$ ) by mass spectrometry.

\section{MATERIAL AND METHODS}

The ATLAS-MAT model CH4 mass spectrometer was equipped with an admission system by molecular flow and a single ion collector with a Faraday cup. The vacuum line was built of Pyrex ${ }^{\circledR}$ and quartz, and the system comprised: an Edwards model 2M8 mechanical vacuum pump; an Edwards model E050 high vacuum diffusion pump; an Edwards active vacuum gauge display (AGD), and an Edwards model APG-M Pirani vacuum filament display. The following reagents, all of analytical grade, were used: $\mathrm{CaSO}_{4} \cdot 2 \mathrm{H}_{2} \mathrm{O} ; \mathrm{CaCl}_{2} \cdot 2 \mathrm{H}_{2} \mathrm{O} ; \mathrm{H}_{3} \mathrm{PO}_{4}$ and $\mathrm{NaH}_{2} \mathrm{PO}_{4} \cdot \mathrm{H}_{2} \mathrm{O}$.

\section{Production of ${ }^{34} \mathrm{~S}$-labeled single superphosphate (SSP)}

The SSP labeled with the ${ }^{34} \mathrm{~S}$ isotope was obtained from a chemical reaction in stoichiometric amounts between $\mathrm{Ca}\left(\mathrm{H}_{2} \mathrm{PO}_{4}\right)_{2}$ and $\mathrm{Ca}^{34} \mathrm{SO}_{4} \cdot 2 \mathrm{H}_{2} \mathrm{O}$. Calcium sulfate $\left(\mathrm{Ca}^{34} \mathrm{SO}_{4} .2 \mathrm{H}_{2} \mathrm{O}\right)$ enriched with $5.85 \pm$ 0.01 atoms $\%$ of ${ }^{34} \mathrm{~S}$ was initially produced as shown by Rossete et al. (2006). The $\mathrm{Ca}\left(\mathrm{H}_{2} \mathrm{PO}_{4}\right)_{2}$ reagent was obtained from the chemical reaction between $\mathrm{CaCl}_{2} \cdot 2 \mathrm{H}_{2} \mathrm{O}$ and $\mathrm{H}_{3} \mathrm{PO}_{4}$ in stoichiometric amounts, according to the reaction shown in Equation 1.

$$
\mathrm{CaCl}_{2} \cdot 2 \mathrm{H}_{2} \mathrm{O}+2 \mathrm{H}_{3} \mathrm{PO}_{4} \rightarrow \mathrm{Ca}\left(\mathrm{H}_{2} \mathrm{PO}_{4}\right)_{2}+2 \mathrm{H}_{2} \mathrm{O}+2 \mathrm{HCl}
$$

After running for approximately $72 \mathrm{~h}$, the produced $\mathrm{Ca}\left(\mathrm{H}_{2} \mathrm{PO}_{4}\right)_{2}$ was dried at $60^{\circ} \mathrm{C}$ to eliminate water and the excess acid possibly formed during the reaction, and its yield production was evaluated by gravimetry. Next, $10 \mathrm{mg} \mathrm{Ca}\left(\mathrm{H}_{2} \mathrm{PO}_{4}\right)_{2}$ were dissolved into $100 \mathrm{~mL}$ water and phosphate/calcium concentrations were determined by ICP-AES (Gine et al., 2004). To verify the yield production of contaminant in the production process, the chloride concentration was determined by spectrometry (Zagatto et al., 1981). Next, the reaction between the produced $\mathrm{Ca}\left(\mathrm{H}_{2} \mathrm{PO}_{4}\right)_{2}$ and the ${ }^{34} \mathrm{~S}$-labeled $\mathrm{Ca}^{34} \mathrm{SO}_{4} \cdot 2 \mathrm{H}_{2} \mathrm{O}(5.81 \pm 0.01$ atoms $\%$ of ${ }^{34} \mathrm{~S}$ ) was developed. After running for 7 days, the labeled SSP was dried at $60^{\circ} \mathrm{C}$ and its yield production was evaluated by gravimetry.

\section{Sample preparation and $\mathbf{S}$ isotopic determination}

The high vacuum line used in the production and purification of $\mathrm{SO}_{2}$ with subsequent ${ }^{34} \mathrm{~S}$ isotopic determination (atoms $\%$ of ${ }^{34} \mathrm{~S}$ ) by mass spectrometry is shown in Figure 1. According to the proposed pro-

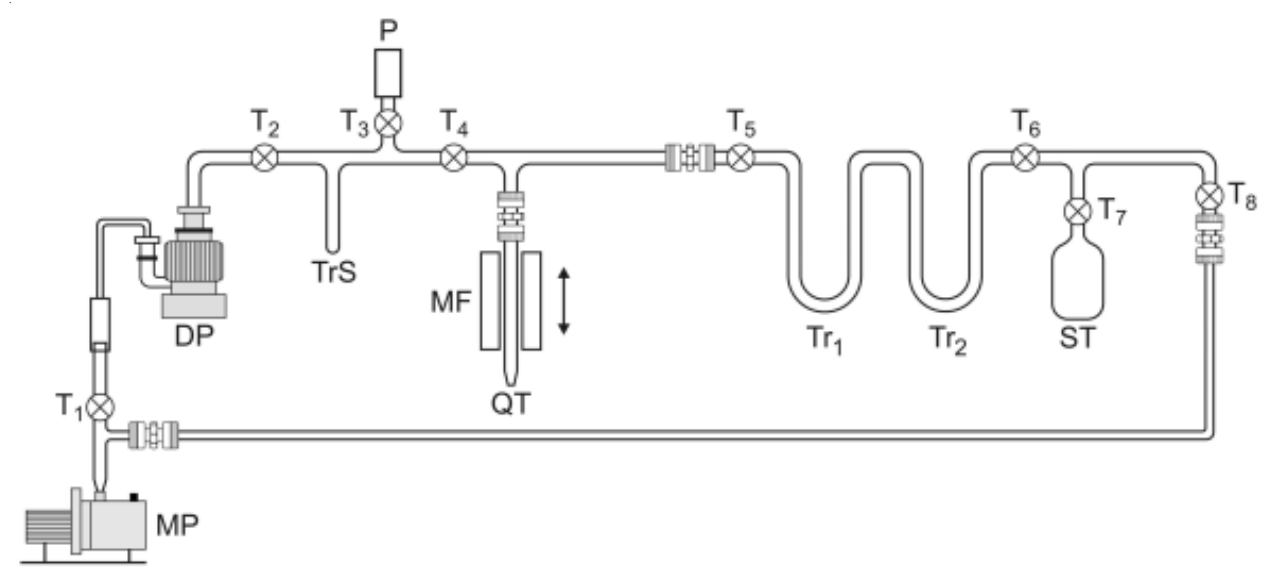

Figure 1 - High vacuum line used in the production and purification of $\mathrm{SO}_{2}$. QT $=$ quartz tube; $\mathrm{MF}=\operatorname{movable}$ furnace $\left(900^{\circ} \mathrm{C}\right) ; \mathrm{Tr}_{1}=$ trap containing dry ice plus ethanol $\left(-70^{\circ} \mathrm{C}\right) ; \mathrm{Tr}_{2}=$ trap containing liquid nitrogen $\left(-196^{\circ} \mathrm{C}\right)$; ST: stock sample tube; $\mathrm{P}=\mathrm{Pirani}$ vacuum gauge filament sensor (Edwards); $\mathrm{TrS}=$ security trap containing liquid nitrogen $\left(-196^{\circ} \mathrm{C}\right) ; \mathrm{DP}=$ diffusion pump (high vacuum); $\mathrm{MP}=$ mechanical pump (previous vacuum); $\mathrm{T}_{1}$ to $\mathrm{T}_{8}=$ Taps 
cedure, $10.00 \mathrm{mg}$ of labeled SSP (approximately 1.35 $\mathrm{mg} \mathrm{S}$ ) and $60 \mathrm{mg}$ sodium metaphosphate were placed inside a quartz tube of $30 \mathrm{~cm}$ length. The sodium metaphosphate was obtained by submitting approximately $10 \mathrm{~g} \mathrm{NaH}_{2} \mathrm{PO}_{4} \cdot \mathrm{H}_{2} \mathrm{O}$ at $200^{\circ} \mathrm{C}$ for $2 \mathrm{~h}$ to remove structural water and possible organic compounds formed. The mass ratio between superphosphate and $\mathrm{NaPO}_{3}$ was 1:6 (w/w) (Halas \& Wolacewicz, 1981). The quarts tube (QT) was then connected into the high vacuum line (Figure 1) and the vacuum system was activated by mechanic (MP) and diffusion (DP) pumps. A bottle containing dry ice plus ethanol solution $\left(-70^{\circ} \mathrm{C}\right)$ and another containing liquid nitrogen $\left(-196^{\circ} \mathrm{C}\right)$ were introduced around the $\operatorname{Tr}_{1}$ and $\operatorname{Tr}_{2}$ traps, respectively. The objective of the traps was to retain water vapor in $\mathrm{Tr}_{1}$ and $\mathrm{SO}_{2}$ (formed during the combustion process) in $\operatorname{Tr}_{2}$. The high vacuum line configuration was based on the method developed by Bailey \& Smith (1972).

In the next step, the MF furnace adjusted to $900^{\circ} \mathrm{C}$ is moved to the QT tube and is heated for approximately 10 min to produce $\mathrm{SO}_{2}$ after the combustion reaction between SSP and $\mathrm{NaPO}_{3}$. Depending on the $\mathrm{O}_{2}$ partial pressure, an undesirable production of $\mathrm{SO}_{3}$ may occur, with consequent isotopic fractionation. In order to retain oxide compounds formed during the combustion process and to convert $\mathrm{SO}_{3}$ to $\mathrm{SO}_{2}$ thus avoiding isotopic fractionation (Yanagisawa \& Sakal, 1983; Rafter, 1957) a metallic copper ring supported by a piece of quartz wool was placed inside the QT tube approximately $2 \mathrm{~cm}$ above the volume occupied by the sample and the $\mathrm{NaPO}_{3}$ reagent. The $\mathrm{SO}_{2}$ gas retained inside the $\mathrm{Tr}_{2}$ trap was then transferred into the stock tube (ST) by replacing the bottle containing liquid $\mathrm{N}_{2}$ from the trap $\mathrm{Tr}_{2}$ to the stock sample tube (ST). Next, the ST tube containing $\mathrm{SO}_{2}$ gas was removed from the high vacuum line and connected to the mass spectrometer admission system and the isotopic determination of S (atoms \% of ${ }^{34} \mathrm{~S}$ ) was accomplished (Bendassolli et al., 1997).

The mass spectrometer equipment worked with an admission system heated to $60^{\circ} \mathrm{C}$ due to the polarity of the $\mathrm{SO}_{2}$ molecules, thus avoiding interference on the analysis. A cryogenic trap $\left(\mathrm{Tr}_{1}\right)$ containing dry ice and ethanol $\left(-70^{\circ} \mathrm{C}\right)$ was adapted on the spectrometer admission system to retain water from coming the samples.

\section{RESULTS AND DISCUSSION}

With regard to the stoichiometric reaction between $\mathrm{H}_{3} \mathrm{PO}_{4}$ and $\mathrm{CaCl}_{2} \cdot 2 \mathrm{H}_{2} \mathrm{O}$, using $14.7 \mathrm{~g}$ of $\mathrm{CaCl}_{2} \cdot 2 \mathrm{H}_{2} \mathrm{O}$ for each test and slowly adding $13.5 \mathrm{~mL}$ of concentrated $\mathrm{H}_{3} \mathrm{PO}_{4}$, it should be theoretically pos- sible to obtain $27.0 \mathrm{~g} \mathrm{Ca}\left(\mathrm{H}_{2} \mathrm{PO}_{4}\right)_{2}$, considering the $\mathrm{HCl}$ mass formed in the process. Based on the theoretical value, the yield conversion (\%) and total $\mathrm{Ca}\left(\mathrm{H}_{2} \mathrm{PO}_{4}\right)_{2}$ mass lost in the process were calculated. Results are in Table 1, where the $\mathrm{Ca}\left(\mathrm{H}_{2} \mathrm{PO}_{4}\right)_{2}$ mass produced and the yield conversion values for each test can be seen.

The concentrations of $\mathrm{Ca}^{2+}$ and $\mathrm{PO}_{4}^{2-}$ samples produced in $\mathrm{Ca}\left(\mathrm{H}_{2} \mathrm{PO}_{4}\right)_{2}$ as determined by ICP-AES (Gine et al., 2004) were estimated to be 17 and $80 \%$ (w/w), respectively. Results were considered satisfactory and in agreement with the gravimetric method.

In relation to the chlorine determination exploring the flow injection analysis system (FIA), the contamination by chlorine in the $\mathrm{Ca}\left(\mathrm{H}_{2} \mathrm{PO}_{4}\right)_{2}$ production process was approximately $5 \%$. This contamination is not significant, thus allowing the application of the ${ }^{34} \mathrm{~S}-$ labeled compound in agronomic studies without interferences. After the analysis related to the yield production of ${ }^{34}$ S-labeled SSP by the gravimetric method, results showed yield conversion values of approximately $99 \%$, with a purity level in the labeled compound estimated approximately at $96 \%$, thus confirming the efficiency of the proposed method. In relation to the results obtained in the isotopic determination of $\mathrm{S}$ (atoms \% of ${ }^{34} \mathrm{~S}$ ) in the labeled compound $\left(\mathrm{Ca}^{34} \mathrm{SO}_{4} \cdot 2 \mathrm{H}_{2} \mathrm{O}\right)$ by mass spectrometry, no isotopic fractionation was observed. The results obtained by $\mathrm{S}$ isotopic determination (atoms $\%$ of ${ }^{34} \mathrm{~S}$ ) in the mass spectrometry using $\mathrm{CaSO}_{4} \cdot 2 \mathrm{H}_{2} \mathrm{O}$ p.a. with natural abundance and two different $\mathrm{S}$ compounds for the production of ${ }^{34}$ S-labeled SSP can be observed in Table 2.

Results obtained with the $\mathrm{CaSO}_{4} \cdot 2 \mathrm{H}_{2} \mathrm{O}$ analysis were satisfactory (Table 2), since the natural abun-

Table $1-\mathrm{Ca}\left(\mathrm{H}_{2} \mathrm{PO}_{4}\right)_{2}$ production, mass obtained by the gravimetric method.

\begin{tabular}{lccc}
\hline Test & $\begin{array}{c}\mathrm{Ca}\left(\mathrm{H}_{2} \mathrm{PO}_{4}\right)_{2} \\
\text { produced }\end{array}$ & $\begin{array}{c}\mathrm{Ca}\left(\mathrm{H}_{2} \mathrm{PO}_{4}\right)_{2} \\
\text { lost }\end{array}$ & $\begin{array}{c}\text { Conversion } \\
\text { yield }\end{array}$ \\
\hline $1^{\text {st }}$ & $\mathrm{g}$ & $\mathrm{g}^{*}$ & $\%$ \\
$2^{\text {nd }}$ & 25.8 & 1.2 & 95.6 \\
$3^{\text {rd }}$ & 26.6 & 0.4 & 98.5 \\
Average \pm rsd & $26.2 \pm 0.3$ & $0.8 \pm 0.3$ & $97.2 \pm 1.0$ \\
\hline
\end{tabular}

*Differences between the theoretical $\mathrm{Ca}\left(\mathrm{H}_{2} \mathrm{PO}_{4}\right)_{2}$ mass $(27.0 \mathrm{~g})$ and the mass obtained experimentally

Table 2 - $\mathrm{S}$ isotopic determination (atoms $\%$ of ${ }^{34} \mathrm{~S}$ ).

\begin{tabular}{lc}
\hline Samples & $\begin{array}{c}\text { S determination } \\
\text { (atoms \% of 34S) }\end{array}$ \\
\hline $\mathrm{CaSO}_{4} \cdot 2 \mathrm{H}_{2} \mathrm{O}$ p.a. & $4.33 \pm 0.04$ \\
Labeled $\mathrm{Ca}^{34} \mathrm{SO}_{4} \cdot 2 \mathrm{H}_{2} \mathrm{O}$ & $5.85 \pm 0.01$ \\
Labeled $3 \mathrm{Ca}_{2}\left(\mathrm{H}_{2} \mathrm{PO}_{4}\right)_{2}+$ & $5.83 \pm 0.02$ \\
$7 \mathrm{Ca}^{34} \mathrm{SO}_{4}$ & \\
\hline
\end{tabular}


Rossete et al.

dance of the compound is approximately 4.15 to 4.38 atoms $\%$ of ${ }^{34} \mathrm{~S}$. Results for ${ }^{34} \mathrm{~S}$ determination (atoms $\%$ of ${ }^{34} \mathrm{~S}$ ) using different compounds prove the efficiency of the proposed method, especially in relation to the production of $\mathrm{SO}_{2}$ in the presence of $\mathrm{NaPO}_{3}$ and the isotopic determination of ${ }^{34} \mathrm{~S}$ by mass spectrometry.

\section{CONCLUSIONS}

The proposed method is feasible and suitable for the production of ${ }^{34} \mathrm{~S}$-labeled single superphosphate by the reaction between $\mathrm{Ca}\left(\mathrm{H}_{2} \mathrm{PO}_{4}\right)_{2}$ and $\mathrm{Ca}^{34} \mathrm{SO}_{4} \cdot 2 \mathrm{H}_{2} \mathrm{O}$, and for the production of $\mathrm{SO}_{2}$ in a high vacuum line with $\mathrm{S}$ isotopic determination (atoms \% of ${ }^{34} \mathrm{~S}$ ) by mass spectrometry. The application of the ${ }^{34} \mathrm{~S}$ stable isotope can help identify sulphur sources. Therefore, the production of ${ }^{34} \mathrm{~S}$-labeled single superphosphate represents an important alternative to the application of ${ }^{34} \mathrm{~S}$ aiming at studies related to sulphur dynamics in the soil-plant system.

\section{ACKNOWLEDGEMENTS}

To FAPESP for partial support and infra-structure.

\section{REFERENCES}

AWONAIKE, K.O.; DANSO, S.K.A.; ZAPATA, F. The use of a double isotope (N-15 and S-34) labeling technique to assess the suitability of various reference crops for estimating nitrogen fixation in gliricidia-sepium and leucaena-leucocephala. Plant and Soil, v.155-156, p.325-328, 1993

BAILEY, S.A.; SMITY, I.W. Improved method for the preparation of sulphur dioxide from Barium sulphate for isotope ratio studies. Analytical Chemistry, v.44, p.1542-1543, 1972.

BENDASSOLLI, J.A.; TRIVELIN, P.C.O.; CARNEIRO JR., F.C. Stable sulphur isotope fractionation by anion exchange chromatography production of compounds enriched in ${ }^{34} \mathrm{~S}$. Journal of Brazilian Chemical Society, v.8, p.13-17, 1997.

BISSANI, C.A.; TEDESCO, M.J. O enxofre no solo. In: REUNIÃO BRASILEIRA DE FERTILIDADE DO SOLO, 17., Londrina, 1988. Enxofre e micronutrientes na agricultura. Londrina: EMBRAPA, IAPAR, 1988. p.11.

GINE, M.F.; BELLATO, A.C.S.; MENEGARIO, A.A. Determination of trace elements in serum samples by isotope dilution inductively coupled plasma mass spectrometry using on-line dialysis. Journal of Analytical Atomic Spectrometry, v.19, p.1252$1256,2004$.
HALAS, S.; WOLACEWICZ, W. Direct extraction of sulphur dioxide from sulfates for isotopic analysis. Analytical Chemistry, v.53, p.686-689, 1981 .

HAMILTON, S.D.; CHALK, P.M.; UNDOVICH, M.J.; SMITH, C.J. The measurement of fertilizer- S uptake by plants using radioactive and stable isotopes. Applied Radiation and Isotopes, v.42, p.1099-1101, 1991.

HAVLIN, J.L.; BEATON, J.D.; TISDALE, S.L.; NELSON, W.L. Phosphorus. In: Soil fertility and fertilizers. Englewood Cliffs: Pearson Prentice Hall, 2005. p.160-197.

KROUSE, H.R.; BERNHARD, M.; SCHOENAU, J.J. Applications of stable isotopes techniques to soil sulphur cycling. In: BOUTTON, T.W.; YAMASAKI, S. (Ed.) Mass spectrometry of soil. New York: Marcel Dekker, 1996. p.246-285.

MAXIMO, E.; BENDASSOLLI, J.A.; TRIVELIN, P.C.O.; ROSSETE, A.L.R.M.; OLIVEIRA, C.R.; PRESTE, C.V. Produção de sulfato de amônio duplamente marcado com os isótopos estáveis ${ }^{15} \mathrm{~N}$ e ${ }^{34}$ S. Química Nova, v. 28, p. 211-216, 2005.

RAFTER, T.A. The preparation of sulphur dioxide for mass spectrometer examination. Journal of Science and Technology, v.38, p.849-857, 1957.

ROSSETE, A.L.R.M.; BENDASSOLLI, J.A.; MAXIMO, E.; SANT ANA FILHO, C.R.; IGNOTO, R.F. Production of ${ }^{34} \mathrm{~S}$ labeled gypsum $\left(\mathrm{Ca}^{34} \mathrm{SO}_{4} \cdot 2 \mathrm{H}_{2} \mathrm{O}\right)$. Scientia Agricola, v.63, p.399-404, 2006.

SHARMA, V.K.; KAMATH, M.B. Effect of sulphur, phosphorus and calcium on sulphur utilization by mustard (Brassica juncea L.) and Pea (Pissum sativum L.). Journal of Nuclear Agriculture and Biology, v.20, p.123-127, 1991.

TISDALE, S.L.; RENEAU, R.B.; PLATOU, J.S. Atlos of sulphur deficiencies. In: TABATABAI, M.A. (Ed.) Sulphur in agriculture. Madison: ASA, CSSA, SSSA, 1986. p.295-322.

TRIVELIN, P.C.O.; BENDASSOLLI, J.A.; CARNEIRO JR., F.; MUROAKA, T. Sulphur utilization by rice and crotalaria juncea from sulfate $-{ }^{34} \mathrm{~S}$ applied to the soil. Scientia Agricola, v.59, p.205-207, 2002.

YANAGISAWA, F.; SAKAL, H. Thermal decomposition of barium sulfate-vanadium pentaoxide-silica glass mixtures for preparation of sulphur dioxide in sulphur isotope ratio measurements. Analytical Chemistry, v.55, p.985-987, 1983.

ZAGATTO, E.A.G.; JACINTO, A.O.; REIS, B.F.; KRUG, F.J.; PESSENDA, L.C.R.; MORTATTI, J.; GINÉ, M.F. Manual de análise de plantas e águas empregando sistemas de injeção em fluxo. Piracicaba: USP/CENA, 1981. 45p.

ZHAO, F.J.; VERKAMPEN, K.C.J.; BIRDSEY, M.; BLAKE-KALFF, M.M.A.; McGRATH, S.P. Use of the enriched stable isotope ${ }^{34} \mathrm{~S}$ to study sulphur uptake and distribution in wheat. Journal of Plant Nutrition, v.24, p.1551-1560, 2001

Received July 28, 2006

Accepted September 18, 2007 